\title{
РОЗРОБКА НАВЧАЛЬНО-МЕТОДИЧНОГО ЗАБЕЗПЕЧЕННЯ ЗА ДИСТАНЦІЙНИМ КУРСОМ ДЛЯ АБІТУРІЕНТІВ «ВСТУП ДО ФАХУ 051 - «ЕКОНОМІКА»»
}

\section{Приходько Д.О., канд. екон. наук, доцент}

Харківський національний автомобільно-дорожній університет

Постановка проблеми. Сьогодні в умовах актуальності та популярності Інтернет-ресурсів, а також мобільності людей, заклади вищої освіти (ЗВО) мають адаптуватися до запитів Інтернет-користувачів і процесів діджиталізації країни, тобто надавати доступ до широкого контенту, у якому висвітлено умови вступу та зарахування до навчального закладу, стан матеріальної бази 3ВО, дані професорсько-викладацького складу, вартість навчання та його форми, перелік спеціальностей і можливих варіантів працевлаштування та ін. Зараз учасникам ринку освітніх послуг, як ніколи раніше, важливо бути присутніми в інформаційному просторі, адже вони зазнають трансформаційних процесів, між ними посилюється конкурентна боротьба, кожен ЗВО прагне залучити якомога більше абітурієнтів та відповідного фінансування.

Для того, щоб завлекти абітурієнтів до вступу у певний ЗВО, необхідно активувати усі доступні та можливі способи донесення до абітурієнтів та їх батьків інформації про 3ВО: профорієнтаційна робота у школах, технікумах, ліцеях, реклама у ЗМІ, реалізація «теорії шести рукостискань», запуск «сарафанного радіо», просування в Інтернеті web-сайту, реалізація заходів public relations, загалом - формування позитивного іміджу ЗВО в очах суспільства.

Період карантинного режиму, що пов'язаний зі світовим поширенням хвороби COVID-19, і процес діджиталізації суспільства актуалізують залучення абітурієнтів до вступу в конкретний ЗВО, навіть на конкретні спеціальності, через Інтернет-платформи та спеціально створені дистанційні програми для абітурієнтів, серед яких курси дистанційного навчання для абітурієнтів «Вступ до фаху».

Аналіз останніх досліджень і публікацій. Згідно з М. Сімосон і Г. Берг дистанційне навчання $\epsilon$ формою навчання, в якій основними елементами $\epsilon$ фізичне розділення викладачів і учнів під час навчання та використання різних технологій для полегшення спілкування між учнем і вчителем [1]. У праці Дж. Тракслер зазначено, що зараз багато університетів використовують цифрові технології для досягнення більш віддалених територій та звертаються до студентів, які можуть навчатися цілком віддалено і повністю в Інтернеті [2]. М. Рожновський зазначає, що дистанційне навчання сьогодні набуває значної популярності внаслідок спрощення доступу до навчально-методичних матеріалів, економії часу, прозорості навчального процесу [3]. Г. Даценко та 3. Сузанська дистанційне навчання розглядали як засіб стимулювання самоосвіти, С. Шклярський розглядав мобільні технології в навчальному 
процесі вищого навчального закладу [4]. В. Осецький та І. Татомир зазначають, що в Україні формат масово відкритих онлайн-курсів успішно використовується як для викладання шкільних предметів, так і для підготовки маибутніх абітурієнтів до проходження зовнішнього незалежного оцінювання [5]. В. Кухаренко багато своїх наукових праць присвятив технології розробки дистанційного курсу, змішаному та дистанційному навчальним процесам, компетентностям тьютора. Так, у його праці [6] згадується перелік можливих відкритих дистанційних курсів, які можна реалізувати викладачами навчальних закладів, у тому числі «Вступ до фаху», який створюється для того, щоб допомогти абітурієнтам визначитися 3 напрямком подальшого навчання, сформувати уявлення про особливості майбутньої спеціальності, щоб свідомо підійти до питання вибору своєї професії.

Невирішені складові загальної проблеми. В умовах зростаючої важливості впровадження дистанційної форми навчання у різних освітніх закладах задля отримання ними довгострокових конкурентних переваг, у тому числі під час профорієнтаційної діяльності, виникає необхідність у розробленні дистанційних курсів навчання «Вступ до фаху» за відповідними спеціальностями, у тому числі за спеціальністю 051 - «Економіка», яка поки що не має єдиного методичного забезпечення зі структури, змісту та програми такого курсу.

Формулювання цілей статі. Метою даного дослідження є розроблення навчально-методичного забезпечення за дистанційним курсом для абітурієнтів «Вступ до фаху 051 - «Економіка»»».

Виклад основного матеріалу дослідження. Залучення абітурієнтів до ЗВО шляхом створення та просування дистанційного курсу «Вступ до фаху» за спеціальністю 051 - «Економіка» обумовлено реалізацією таких головних цілей курсу: осмислення на аналіз фахової діяльності абітурієнтом; вибір напряму фахової підготовки; підготовка до навчального процесу в університеті.

Для того, щоб зазначені цілі курсу були досягнуті, необхідно реалізувати такі завдання: створення зручного доступу до ресурсу та відповідних умов роботи у ньому; створення упорядкованого, цікавого, чітко зрозумілого змісту (контенту) щодо майбутньої спеціальності абітурієнта.

Реалізувати ці завдання можливо через віртуальні навчальні середовища, тобто платформи для навчання, які надають іï учасникам (зазвичай це викладачі, учні та адміністратори) широкий набір інструментів для комп'ютеризованого навчання, в тому числі дистанційного. Однією 3 таких платформ $є$ Moodle (Modular Object-Oriented Dynamic Learning Environment) [7]. Moodle можна використовувати в навчанні школярів, студентів, при підвищенні кваліфікації, бізнес-навчанні, як в комп'ютерних класах навчального закладу, так i для самостійної роботи вдома. Moodle - це найбільш досконала та поширена в Україні і в світі система такого призначення. На даний момент Moodle вже має 129 мільйонів користувачів в усьому світі й продовжує розвиватися темпами, значно швидшими, ніж iï конкуренти. Moodle - це безкоштовна, відкрита система. Вона не потребує для своєї роботи жодного 
платного програмного забезпечення. Тобто кожний навчальний заклад може впровадити у себе не просто безкоштовну та найбільш досконалу, а ще й абсолютно ліцензійну систему, не витративши жодної копійки на придбання програмного забезпечення. При цьому користувач може вносити зміни у код у відповідності до своїх потреб [8].

Отже, перевагами дистанційного курсу для абітурієнтів «Вступ до фаху 051 - «Економіка»» на базі віртуальної навчальної платформи Moodle $\epsilon$ : мобільність - отримати доступ до курсу можна 3 комп’ютера, ноутбука, планшета, мобільного телефона у будь-якому зручному для користувача місці та часі за наявності Інтернету (користувач не прив'язується до конкретного місця та часу виконання); діяльність - курс «Вступ до фаху 051 «Економіка»»»» орієнтований на навчальний процес, де під час дистанційного курсу тьютор курсу зможе навчити абітурієнта деякій діяльності у рамках відповідної спеціальності; наявність зворотного зв'язку - протягом усього навчання абітурієнта супроводжує тьютор курсу, який консультує його, перевіряє правильність виконаних завдань, відповідає на питання, до того ж, тьютор дистанційного курсу - це викладач кафедри за відповідною спеціальністю; безкоштовний достуn - навчання за дистанційним курсом «Вступ до фаху 051 - «Економіка»» створюється на безоплатній основі, що надає можливість перейнятися особливостями навчання за відповідною спеціальністю, не витрачаючи гроші; короткий термін навчання - протягом короткого проміжку часу абітурієнт зможе отримати певні знання в області відповідної спеціальності, враження про майбутнє навчання за фахом; усвідомлений вибір фаху - записуючись на такий дистанційний курс, абітурієнт залучається до навчання та діяльності, які розкривають особливості його майбутньої спеціальності, та відповідно, він обирає для себе майбутню професію.

Структура дистанційного курсу на базі платформи Moodle може складається 3 елементів (або ресурсів), серед яких «сторінка», «завдання», «чат», «форум», «гра», «тест», «анкетне опитування», «файл», «глосарій» та ін.

Тому, на погляд автора, з урахуванням рекомендацій [3; 6], структурні елементи дистанційного курсу «Вступ до фаху 051 - «Економіка»» доцільно представляти у вигляді трьох основних блоків. Анотація курсу (невеликий за розміром матеріал, який презентує курс, - повна назва курсу, коротка характеристика курсу, презентаційна картинка курсу). Загальна інформація про курс (інформаційні сторінки, у яких висвітлені такі питання, за якими абітурієнт вирішує, наскільки корисним буде для нього матеріал курсу, які знання він отримає та як у майбутньому він зможе їх використати, інформація про тьютора, кафедру та спеціальність, особливості роботи у курсі та ін.). Навчальна частина курсу (інформаційні блоки за навчальними тижнями та темами, що включають визначені цілі заняття за таксономією Блума [9], теоретичний i практичний навчальний матеріал, форуми, чати). Детальне компонування елементів за дистанційним курсом для абітурієнтів «Вступ до фаху 051 - «Економіка»» та, відповідно, його структура представлені на рис. 1. 
Під час створення дистанційного курсу значну увагу варто приділяти змісту структурних елементів. Блок анотації курсу є свого роду «обличчям курсу», рекламним повідомленням, тому його зміст має візуально привертати увагу абітурієнта до курсу та під час прочитання перших речень спонукати до запису на курс. Зміст блоку загальної інформації про курс повинен спонукати до навчання за курсом, а зміст блоку навчальної частини - спонукати до подальшого вступу до ЗВО та навчання за відповідною спеціальністю.

Зміст окремих структурних елементів дистанційного курсу «Вступ до фаху 051 - «Економіка»», які можуть знаходитися у блоці загальної інформації про курс, може бути представлений наступним чином.

Сторінка з наданням відповідей на питання «Чому потрібно вивчати даний курс?» (такі відповіді допоможуть зацікавити абітурієнта в необхідності навчання за відповідним курсом та у подальшому навчанні за відповідною спеціальністю).

«Економіка - це наука про те, як отримувати більше задоволення від життя» (Бернард Шоу). Економіка - це частина нашого життя, а ми - частина економічної системи. Ми купуємо товари і послуги, виробляємо їх, платимо податки, зберігаємо гроші в банках, беремо кредити. Тобто ми беремо участь в економічному житті. Економічна діяльність крайни має вплив на кожного 3 нас - це наші зарплати, ціни на ринку, ціни на енергоресурси. Економіка здійснює наибезпосередніший вплив на життя людини, особливо на ії̈ добробут. Економіка відображається в новинах, численних телепрограмах, політичних ток-шоу, інтелектуальних обговореннях. Економіка дає змогу встановити закономірності та дати відповіді на питання про те, чи підвищиться пенсійний вік, чи будуть виведені «з тіні» зарплати, чи стане в нашій країні більше робочих місць? 3 економічними процесами ми стикаємося щодня. Ми живимо в економічному оточенні. Чому б на цьому не заробляти гроші?

Файл-презентаиія дистаниійного курсу «Вступ до фаху 051 «Економіка»» (тут висвітлюються головні аспекти курсу та навчання у ньому). Презентація може включати таку інформацію.

- Н Надання відповідей на питання «Про що курс?» (тут розкриваються особливості курсу, що таке «економіка», яка головна функція економіки, мета економіки). «Вступ до фаху 051 - «Економіка»» - це курс, який розкриває сутність і значення економіки, ознайомлює абітурієнтів 3 майбутньою спеціальністю за фахом 051 - «Економіка». Економіка - це наука про те, яким чином люди взаємодіють один з одним в процесі виробництва та розподілу того, що вони споживають. Головна функція економіки полягає в тому, щоб постійно створювати такі блага, які необхідні для життедіяльності людей і без яких суспільство не зможе розвиватися. Економіка допомагає задовольнити потреби людини в світі обмежених ресурсів. Мета економіки - підтримка та продовження життя суспільства. Для цього виробляються різноманітні матеріальні блага.

- Призначення, тривалість курсу (тут розкривається те, на кого спрямований дистанційний курс та визначається термін навчання за курсом). 
Дистанційний курс «Вступ до фаху 051 - «Економіка»» розроблено для всіх бажаючих отримати універсальну освіту економічної спрямованості, що сприяє працевлаштуванню на багатьох підприємствах. Навчання за дистанційним курсом передбачає 4 навчальні тижні, тобто 1 місяць.

- Ц Цілі, задачі, предмет курсу. Цілі курсу: формування у абітурієнтів системи знань про сутність і зміст економіки в сучасних ринкових умовах. Задачі курсу: вивчення основних понять, систем і алгоритмів, формування знань, вмінь та уявлень про теоретичні положення економіки; набуття практичних навичок розв'язання конкретних економічних завдань; формування вмінь творчого пошуку резервів удосконалення економічної діяльності підприємства, самозайнятості. Предмет курсу: педагогічно-адаптована система понять про методологію та інструментарій економічної діяльності.

- Результати. Після засвоєння курсу абітурієнт повинен: знати: сутність і зміст економіки, основні положення економічної науки, засади економіки і підприємництва, особливості використання спеціальності у житті; вміти: обробляти економічну інформацію, розраховувати і аналізувати економічні показники, приймати економічні рішення у повсякденному житті; мати уявлення в області прийняття рішень з економічної діяльності.

Сторінка з інструкиією до навчання у курсі (тут висвітлюються особливості роботи з курсом). 1) Дистанційний курс складається з 4 навчальних тижнів. Навчальний тиждень дорівнює 1 заняттю - вивченню 1 теми. 2) План роботи абітурієнтів у курсі (рекомендований маршрут вивчення кожної теми): a) опрацювання теоретичного матеріалу та надання відповідей на питання самоконтролю; b) виконання практичних завдань; с) розв'язання кросвордів; d) участь у дискусіях на форумі та у чаті (поточне консультування, обговорення питань, що виникли під час вивчення теми, інше). 3) Вивчення кожної навчальної теми оцінюється тьютором максимальною оцінкою в 100 балів. Оцінювання результатів роботи за кожною темою здійснюється наприкінці навчального тижня. Оцінка за виконане практичне завдання складає від 0 до 50 балів. Оцінка за розв'язаний кросворд складає від 0 до 50 балів. Оцінка за участь у форумі складає від 0 до 10 балів. Оцінка за участь у чаті складає від 0 до 50 балів. Участь у розмові, коментування інших повідомлень, допомога в форумах і чатах заохочується також додатковими балами: від 0 до 5. 4) Якщо виникають якісь питання щодо роботи у курсі учасникам необхідно звернутися у «Форум взаємодопомоги». 5) Запорукою успішного навчання за курсом «Вступ до фаху 051 - «Економіка»» $є$ виконання всіх завдань. Підсумкова оцінка знань за дистанційним курсом визначається як середньоарифметичне значення оцінок за усіма завданнями тем, що входять до курсу.

Висновки 3 проведеного дослідження. Визначено, що дистанційний курс для абітурієнтів «Вступ до фаху 051 - «Економіка»» доцільно реалізовувати на базі віртуальної навчальної платформи Moodle, яка $\epsilon$ найбільш досконалою та поширеною в Україні і в світі. Перевагами навчання за даним курсом в межах обраного віртуального навчального середовища Moodle $\epsilon$ : 
мобільність; діяльність; наявність зворотного зв'язку; безкоштовний доступ; короткий термін навчання; усвідомлений вибір фаху. Структурні елементи дистанційного курсу «Вступ до фаху 051 - «Економіка»» доцільно представляти у вигляді трьох основних блоків: анотація курсу; загальна інформація про курс; навчальна частина курсу. Зміст структурних елементів даного курсу слід наповнювати інформацією, яка привертала 6 увагу абітурієнтів до курсу, спонукала до запису на курс, до навчання за курсом, до вступу до ЗВО за відповідною спеціальністю. Наукова новизна даного дослідження: розроблено навчально-методичне забезпечення за дистанційним курсом для абітурієнтів «Вступ до фаху 051 - «Економіка»», а саме - структуру та зміст елементів курсу. 3 практичним застосуванням розробленого навчальнометодичного забезпечення за дистанційним курсом «Вступ до фаху 051 «Економіка»» можна ознайомитися за посиланням [10]. Даний дистанційний курс $\epsilon$ сертифікованим та рекомендованим до навчального процесу в Харківському національному автомобільно-дорожньому університеті.

\section{Перелік посилань}

1. Simonson M., Berg G. A. Distance learning. ENCYCLOPAEDIA BRITANNICA : website. URL: https://cutt.ly/5yfstfV (date of access: 14.02.2020).

2. Traxler J. Distance Learning - Predictions and Possibilities. Education Sciences. 2018. 8 (1), 35. DOI:10.3390/educsci8010035.

3. Рожновський М. В. Методичні рекомендації щодо формування дистанційних курсів та використання технологій дистанційного навчання в освітньому процесі ОНАЗ ім. О. С. Попова. Одеса, 2018. 20 с. URL: https://cutt.ly/6yfaV3F (дата звернення: 14.02.2020).

4. Дистанційне навчання як сучасна освітня технологія : матеріали міжвузівського вебінару, 31 березня 2017 р. Вінниця : ВТЕІ КНТЕУ, 2017. 102 c. URL: http://www.vtei.com.ua/images/VN/31_03.pdf (дата звернення: 14.02.2020).

5. Осецький В. Л., Татомир І. Л. Роль масових відкритих онлайнкурсів у сучасному «освітньому ландшафті». Економіка України. 2017. № 12 (673). C. 86-98.

6. Кухаренко В. М. Система підготовки кадрів дистанційного навчання. Проблеми впровадження дистанційного навчання в освітньому прочесі вищих військових навчальних закладів та можливі шляхи їх вирішення : 3б. матеріалів І-ої міжнар. наук.-практ. конф. Київ : НУОУ, 2018. С. 98-104.

7. Moodle. The official website of the learning management system : website. URL: https://moodle.org/?lang=ru (date of access: 14.02.2020).

8. Що таке Moodle. Ресурс украӥнської спільноти користувачів Moodle : веб-сайт. URL: https://cutt.ly/1yfa3w6 (дата звернення: 14.02.2020).

9. Карпова Я. Таксономия Блума как методика оценки успешности обучения. Мотивация жизни : веб-сайт. URL: https://cutt.ly/Syd91Bf (дата обращения: 14.02.2020).

10. Приходько Д. О. Сертифікований дистанційний курс «Вступ до 
фаху «051 - Економіка»», що рекомендовано до навчального процесу в університеті. ХНАДУ, ЛІТОС. Харків, 2018. URL: https://cutt.ly/8yhTLIl (дата звернення: 14.02.2020).

\section{References}

1. Simonson, M., Berg, G. A., «Distance learning», ENCYCLOPADIA BRITANNICA, available at : https://cutt.ly/5yfstfV (last accessed 14.02.2020).

2. Traxler, J. (2018), «Distance Learning - Predictions and Possibilities», Education Sciences, 8 (1), 35. DOI:10.3390/educsci8010035.

3. Rozhnovskyi M. V., (2018), Methodical recommendations for the formation of distance courses and the use of distance learning technologies in the educational process Odessa National O.S. Popov Academy of Telecommunications [Metodychni rekomendatsii shchodo formuvannia dystantsiinykh kursiv ta vykorystannia tekhnolohii dystantsiinoho navchannia $v$ osvitnomu protsesi ONAT im. O. S. Popova], Odessa, 20 p., available at : https://cutt.ly/6yfaV3F (last accessed 14.02.2020).

4. Distance learning as a modern technological education, Materials of an inter-university webinar, Vinnytsia, March 31, 2017, VITE KNUTE, Vinnytsia, 102 p., available at : http://www.vtei.com.ua/images/VN/31_03.pdf (last accessed 14.02.2020).

5. Osetskyi, V. L., Tatomyr, I. L. (2017), «The role of massive open online courses in the modern «educational landscape»» [«Rol masovykh vidkrytykh onlainkursiv u suchasnomu «osvitnomu landshafti»»], Ukraine economy, No. 12 (673), P. 86-98.

6. Kukharenko, V. M. (2018), «System of training of distance learning personnel» [«Systema pidhotovky kadriv dystantsiinoho navchannia»], Problems of introduction of distance learning in the educational process of higher military educational establishments and possible ways of their solution, Proceedings of the 1st International research-practice Conference, NDUU, Kyiv, P. 98-104.

7. Moodle, available at : https://moodle.org/?lang=ru (last accessed 14.02.2020).

8. Resource of the Ukrainian community of Moodle users, What is Moodle, available at : https://cutt.ly/1yfa3w6 (last accessed 14.02.2020).

9. Karpova, Ya., «Bloom's taxonomy as a methodology for assessing the success of training» [«Taksonomiya Bluma kak metodika otsenki uspeshnosti obucheniya»], Life motivation, available at : https://cutt.ly/Syd91Bf (last accessed 14.02.2020).

10. Prykhodko, D. O. (2018), «Certified distance course «Introduction to specialty $051-\ll$ Economics», which is recommended for the educational process at the university» [«Sertyfikovanyi dystantsiinyi kurs «Vstup do fakhu «051 Ekonomika»», shcho rekomendovano do navchalnoho protsesu $\mathrm{v}$ universyteti»], KhNAHU, LITOS, Kharkiv, available at : https://cutt.ly/8yhTLIl (last accessed 14.02.2020). 


\section{РЕФЕРАТИ РЕФЕРАТЫ ABSTRACTS}

\section{УДК 378.14+37.018.4+33; JEL Classification: I23, P46, A21, A22}

ПрихоДЬКО Д. О. РОЗРОБКА НАВЧАЛЬНО-МЕТОДИЧНОГО ЗАБЕЗПЕЧЕННЯ ЗА ДИСТАНЦІЙНИМ КУРСОМ ДЛЯ АБІТУРІЕНТІВ «ВСТУП ДО ФАХУ $О 51$ - «ЕКОНОМІКА»»

Mema: розроблення навчально-методичного забезпечення за дистанційним курсом для абітурієнтів «Вступ до фаху 051 - «Економіка»»». Методика дослідження: у роботі були використані загальнонаукові та спеціальні методи і прийоми дослідження: теоретичного узагальнення, аналізу і синтезу; системного і комплексного підходу; абстрактно-логічний метод. Результати: визначено, що дистанційний курс для абітурієнтів «Вступ до фаху 051 - «Економіка»»» доцільно реалізовувати на базі віртуальної навчальної платформи Moodle, яка є найбільш досконалою та поширеною в Україні і в світі. Перевагами навчання за даним курсом в межах обраного віртуального навчального середовища Moodle $є$ : мобільність; діяльність; наявність зворотного зв'язку; безкоштовний доступ; короткий термін навчання; усвідомлений вибір фаху. Структурні елементи дистанційного курсу «Вступ до фаху 051 - «Економіка»» доцільно представляти у вигляді трьох основних блоків: анотація курсу; загальна інформація про курс; навчальна частина курсу. Зміст структурних елементів даного курсу слід наповнювати інформацією, яка привертала б увагу абітурієнтів до курсу, спонукала до запису на курс, до навчання за курсом, до вступу до ЗВО за відповідною спеціальністю. Наукова новизна: розроблено навчально-методичне забезпечення за дистанційним курсом для абітурієнтів «Вступ до фаху 051 - «Економіка»», а саме - структуру та зміст елементів курсу. Практичним застосуванням розробленого навчальнометодичного забезпечення $є$ те, що дистанційний курс для абітурієнтів «Вступ до фаху 051 - «Економіка»» $\epsilon$ сертифікованим та рекомендованим до навчального процесу в Харківському національному автомобільно-дорожньому університеті. Практична значущість: дистанційний курс для абітурієнтів «Вступ до фаху 051 - «Економіка»» надає можливість привернути увагу абітурієнтів до ЗВО та залучити до вступу за відповідною спеціальністю.

Ключові слова: дистанційне навчання; абітурієнт; економіка; спеціальність; вступ; структура; зміст.

УДК 378.14+37.018.4+33; JEL Classification: I23, P46, A21, A22 ПрИхоДЬКО Д. А. РАЗРАБОТКА УЧЕБНО-МЕТОДИЧЕСКОГО ОБЕСПЕЧЕНИЯ ПО ДИСТАНЦИОННОМУ КУРСУ ДЛЯ АБИТУРИЕНТОВ «ВВЕДЕНИЕ В СПЕЦИАЛЬНОСТЬ 051 «ЭКОНОМИКА»»

Цель: разработка учебно-методического обеспечения по дистанционному курсу для абитуриентов «Введение в специальность 051 - «Экономика»». Методика исследования: в работе были использованы общенаучные и 
специальные методы и приемы исследования: теоретического обобщения, анализа и синтеза; системного и комплексного подхода; абстрактно-логический метод. Результаmы: определено, что дистанционный курс для абитуриентов «Введение в специальность 051 - «Экономика»» целесообразно реализовывать на базе виртуальной учебной платформы Moodle, которая является наиболее совершенной и распространенной в Украине и в мире. Преимуществами обучения по данному курсу в рамках выбранной виртуальной учебной среды Moodle являются: мобильность; деятельность; наличие обратной связи; бесплатный доступ; короткий срок обучения; осознанный выбор специальности. Структурные элементы дистанционного курса «Введение в специальность 051 - «Экономика»» целесообразно представлять в виде трех основных блоков: аннотация курса; общая информация о курсе; учебная часть курса. Содержание структурных элементов данного курса следует наполнять информацией, которая привлекала бы внимание абитуриентов к курсу, побуждала к записи на курс, к обучению по курсу, к поступлению в заведение высшего образования по соответствующей специальности. Научная новизна: разработано учебно-методическое обеспечение по дистанционному курсу для абитуриентов «Введение в специальность 051 - «Экономика»», а именно структуру и содержание элементов курса. Практическим применением разработанного учебно-методического обеспечения является то, что дистанционный курс для абитуриентов «Введение в специальность 051 «Экономика»» является сертифицированным и рекомендованным к учебному процессу в Харьковском национальном автомобильно-дорожном университете. Практическая значимость: дистанционный курс для абитуриентов «Введение в специальность 051 - «Экономика»» предоставляет возможность привлечь внимание абитуриентов к заведению высшего образования и поступлению на соответствующую специальность.

Ключевые слова: дистанционное обучение; абитуриент; экономика; специальность; введение; структура; содержание.

UDC 378.14+37.018.4+33; JEL Classification: I23, P46, A21, A22

Prykhodko D. DEVELOPMENT OF EDUCATIONAL AND METHODOLOGICAL SUPPORT FOR THE DISTANCE COURSE FOR ENTRANTS «INTRODUCTION TO SPECIALTY 051 - «ECONOMICS»»

Purpose: development of educational and methodological support for the distance course for entrants «Introduction to specialty 051 - «Economics»». Methodology of research: to meet an aim during the research were used the next general scientific and special methods, skills of research: theoretical generalization, analysis and synthesis; systems and complex approach; abstractly logical method. Findings: it's determined, that the distance course for entrants «Introduction to the specialty $051-$ - Economics»» is advisable to implement on the basis of the virtual training platform Moodle, which is the most advanced and widespread in Ukraine and in the world. The advantages of studying at this course within the chosen virtual 
Moodle learning environment are: mobility; activity; feedback; free access; short term of study; conscious choice of specialty. The structural elements of the distance course «Introduction to the specialty $051-$ «Economics»» should be presented in the form of three main blocks: an abstract of the course; general information about the course; educational part of the course. The content of the structural elements of this course should be filled with information, that would attract the entrants' attention to the course, prompt them to enroll in the course, to study at the course, to enter in the institution of higher education in the relevant specialty. Originality: has been developed educational and methodological support for the distance course for entrants «Introduction to specialty 051 - «Economics»», namely - the structure and content of the elements of the course. The practical implementation of the developed educational and methodological support of the distance course for entrants «Introduction to specialty $051-$ «Economics»» is certified and recommended for the educational process at the Kharkiv National Automobile and Highway University. Practical value: the distance course for entrants «Introduction to specialty 051 «Economics»» provides an opportunity to attract the attention of the entrants to a institution of higher education and to study to the relevant specialty.

Keywords: distance study; entrant; economics; specialty; introduction; structure; content.

\section{Відомості про авторів / Сведения об авторах / About the Authors}

Приходько Дар'я Олександрівна - кандидат економічних наук, доцент, Харківський національний автомобільно-дорожній університет, доцент кафедри економіки і підприємництва, м. Харків, Україна; e-mail: zajada@gmail.com; ORCID: https://orcid.org/0000-0003-3925-4828. Моб. 066-97-44-135.

Приходько Дарья Александровна - кандидат экономических наук, доцент, Харьковский национальный автомобильно-дорожный университет, доцент кафедры экономики и предпринимательства, г. Харьков, Украина.

Prykhodko Daria - PhD in Economics, Associate Professor, Kharkiv National Automobile and Highway University, Associate Professor of the Department of Economics and Entrepreneurship, Kharkiv, Ukraine. 